\title{
A review on the effect of surface finish and cooling rate on solder joint reliability
}

\author{
K. Hardinnawirda, A. M. Zetty Akhtar, I. Siti Rabiatull Aisha \\ \& I. Mahadzhir \\ Faculty of Mechanical Engineering, \\ Universiti Malaysia Pahang, Malaysia
}

\begin{abstract}
With increasing environmental concern over the toxicity of lead $(\mathrm{Pb})$ combined with strict regulations, the use of lead-based solders provides an inevitable driving force for the development of lead-free solder alloys. Many studies have been conducted for the evaluation of the solder joint reliability with respect to solder alloys and surface finishes. However, as the demand of electronic devices is increasing, there is a need to improve the mechanical properties of the solder joint in order to keep up with the current evolution of electronic devices' technology. In this study, the effect of surface finish and cooling rate on solder joint reliability using nickel-based surface finish was summarized. The study focused on nickel based surface finish (ENIG and ENEPIG) with different cooling media, slow (furnace), medium (air) and fast (water). It was found that the type of surface finish and the cooling rate can change the morphology of the solder intermetallic compound (IMC) and directly changes the solder joint mechanical properties. A faster cooling rate was reported to provide finer IMC grains which might be translated into better solder joint strength. The findings presented here may provide a better understanding for further study and facilitate improvements in terms of solder joint reliability.

Keywords: solder alloy, surface finish, interfacial reaction, solder joint and cooling rate.
\end{abstract}

\section{Introduction}

Currently, the demand for electronic gadgets such as personal digital assistants (PDA), tablets, phones, digital music players (MP3), and cameras, has increased 
rapidly. The manufacturing industry have to ensure their products meet the current trend such as small, portable and add more functionality. But the major drawbacks of these portable devices are prone to accidental drops and may cause internal circuit board damage. When an electronic product drops on the ground, the impact force and deformation that is transferred internally to the print circuit board (PCB) can cause brittle fracture at the solder joint interface or by impact fatigue in the solder materials. Thus, the solder joint must be strong enough to endure such incident.

The solder joint reliability can be determined based on its capability to endure optimum temperature, the frequency of on/off power cycling and the possibility of withstand specific mechanical or vibrational stresses put on it such as when dropping. The formation of a strong and reliable solder joint is also dependent on the ability of molten solder to rapidly and uniformly wet the surface finish and interact with it to form a consistent layer of intermetallic at the interface [1-5]. Optimum combination between surface finish layer and solder alloys is one of the most important factors to ensure reliability of the package for the soldering process used in flip chip or ball grid array (BGA) technology [6-8].

Cooling rate is also an important parameter in the solder reflow process because it affects the microstructure of solder alloy as well as the morphology and growth of IMC formed between the solder and its metallization. Hence, affect the mechanical integrity of the joint [9-12].

With the wider applications of surface mount technology and popular trends of ultrafine-pitch design it is imperative to develop and investigate surface finish and cooling rate that can provide higher mechanical properties such as shear strength since based on findings by some researchers, the shear strength of the solder joint lower than $50 \mathrm{MPa}$ [13-15]. Based on the studies made, this paper summarizes the effects of nickel based surface finish and cooling rate on interfacial reaction and solders joint reliability to provide an important basis on nickel surface finish for better understanding.

\section{Interfacial reaction of solder alloy and surface finish}

During soldering process, the molten solder comes in contact with the substrate and a layer of IMC is formed at the solder/substrate interface. IMC formation known to have an influence on solder joint strength that caused either by the IMC structured or thickness. The reaction between the molten solder and $\mathrm{Ni}$ layer resulted in the establishment of different types of IMCs, depend on the types of solders as well as surface finish being applied. For Sn-Ag-Cu solder and ENIG surface finish, during initial reflow, the topmost Au layer dissolved into the molten solder, leaving the Ni layer exposed to the molten SAC solder [16]. The Ni then acts as barrier and prevents $\mathrm{Cu}$ diffusion (from $\mathrm{Cu}$ substrate) into the interface, thus limiting the IMC thickness formed as thin IMC layer (below $4 \mu \mathrm{m}$ ) is desirable to achieve good metallurgical bonding.

Surface finish used can also change the morphology of the IMC formed [17, 18]. Tseng and Duh [19] investigated the interfacial reaction of $\mathrm{Sn}-3.0 \mathrm{Ag}-0.5 \mathrm{Cu}$ solder jointed with ENIG and electroless Ni-P/electroless Pd/immersion $\mathrm{Au}$ 
(ENEPIG). They found that as compared with ENIG joints, the grain size of $(\mathrm{Cu}, \mathrm{Ni}, \mathrm{Pd})_{6} \mathrm{Sn}_{5}$ seemed to be refined by the palladium $(\mathrm{Pd})$ insertion in the ENEPIG joints. This is because $\mathrm{Pd}$ would retard the growth of $\mathrm{Ni}_{3} \mathrm{P}$ and $(\mathrm{Cu}, \mathrm{Ni}, \mathrm{Pd})_{6} \mathrm{Sn}_{5}$ and refine the grain structure of $(\mathrm{Cu}, \mathrm{Ni}, \mathrm{Pd})_{6} \mathrm{Sn}_{5}$ [20]. The composition of $(\mathrm{Cu}, \mathrm{Ni}, \mathrm{Pd})_{6} \mathrm{Sn}_{5}$ was evaluated as 35.0 at $\% \mathrm{Cu}, 23.2$ at $\% \mathrm{Ni}, 0.2$ at $\% \mathrm{Pd}$, and $42.6 \mathrm{at} \% \mathrm{Sn}$. As shown in Figure 1, the morphology of interfacial $(\mathrm{Cu}, \mathrm{Ni})_{6} \mathrm{Sn}_{5}$ and $(\mathrm{Cu}, \mathrm{Ni}, \mathrm{Pd})_{6} \mathrm{Sn}_{5}$ was chunky and needle-like, respectively.
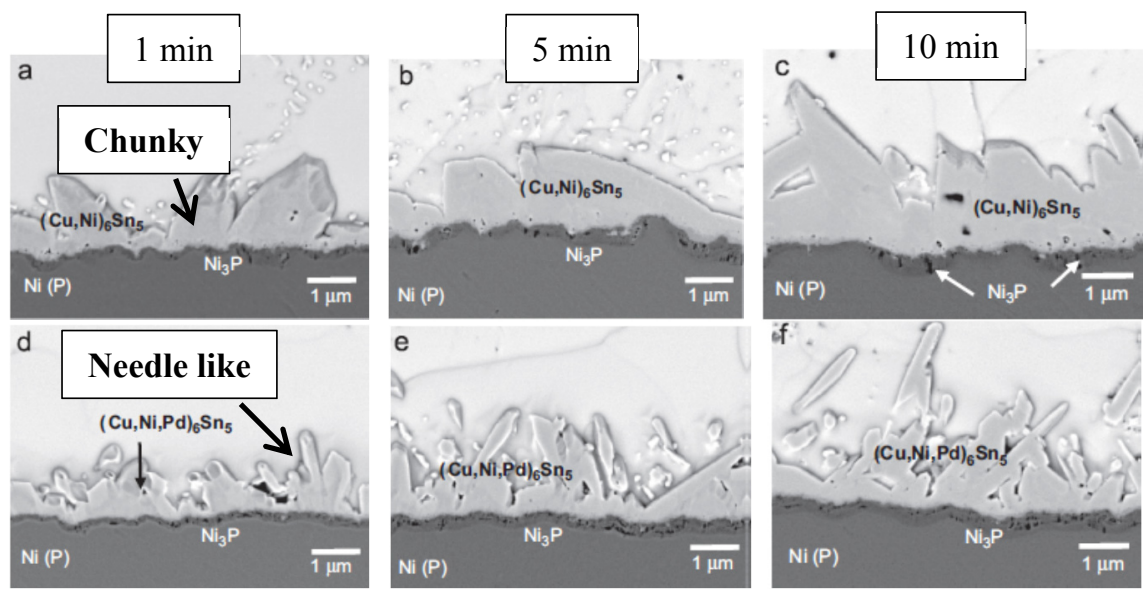

Figure 1: SEM cross-sectional images of interfacial reaction in (a)(c) SAC305/ENIG and (d)-(f) SAC305/ENEPIG solder joints under various reflow times [19].

A comparison between ENEPIG and ENIG surface finish also studied by Lin and Chen [21]. However since there is no reflow process, the Pd and Au layers do not dissolve in the $\mathrm{Sn}$ matrix but remain at the interface and participate in the interfacial reaction to form the $(\mathrm{Pd}, \mathrm{Ni}, \mathrm{Au}) \mathrm{Sn}_{4}$ and $(\mathrm{Au}, \mathrm{Ni}) \mathrm{Sn}_{4}$ phases at the ENEPIG and ENIG based interfaces, respectively after aging at $150^{\circ} \mathrm{C}$. The $(\mathrm{Pd}, \mathrm{Ni}, \mathrm{Au}) \mathrm{Sn}_{4}$ phase was identified to possess the structure of the $\mathrm{PdSn}_{4}$ phase with the solubility of $\mathrm{Ni}$ and $\mathrm{Au}[22]$ that probably structured the (Pd, Ni, $\mathrm{Au})$ $\mathrm{Sn}_{4}$ phase by the same as the initial $\mathrm{AuSn}_{4}$ phase while some $\mathrm{Au}$ atoms were substitutionally replaced by the $\mathrm{Pd}$ and $\mathrm{Ni}$ atoms diffused inward. Another possible mechanism is that the inward diffusion of $\mathrm{Pd}$ transformed the initial $\mathrm{AuSn}_{4}$ phase in the $\mathrm{PdSn} 4$ phase, hence the (Pd, Ni, Au) $\mathrm{Sn}_{4}$ phase possesses the structure of the $\mathrm{PdSn}_{4}$ phase with the dissolution of $\mathrm{Au}$ and $\mathrm{Ni}$ where dissolution of ENEPIG for SAC mentioned to be $0.08 \mu \mathrm{m} / \mathrm{min}$ by Kang et al. [23]. Upon increasing the aging time, the $\mathrm{Sn} /(\mathrm{Pd}, \mathrm{Ni}, \mathrm{Au}) \mathrm{Sn}_{4}$ interface became mechanically weak due to void formation, and fracture easily occurred along the interface. Compare to the interface with the $\mathrm{Au} / \mathrm{Ni}$ surface finish, there were also two IMC formed, (Au,Ni) $\mathrm{Sn}_{4}$ and $\mathrm{Ni}_{3} \mathrm{Sn}_{4}$, that in agreement with a previous study [24]. 


\section{Effect of cooling rate}

Cooling rate is an important parameter in the solder reflow process because it influences microstructure of solder alloy, also the morphology and growth of intermetallic compounds (IMC) formed between solder and its metallization. All these ultimately affect the mechanical integrity of the joint $[9,25,26]$.

Figure 2 shows the reflow profile used on previous studies by different researcher that will be discussed below. Each of them was using different types of profile. He et al. [9] as researcher A heated the Ni-P substrate with $\mathrm{Sn}-3.5 \mathrm{Ag}$ solder at the rate of $2.5^{\circ} \mathrm{C} / \mathrm{s}$ to a peak temperature of $251^{\circ} \mathrm{C}$ and held up to 10 mins while Ochoa et al. [12] as researcher B heated the same type of solder at $240^{\circ} \mathrm{C}$ for only $20 \mathrm{sec}$. Researcher C, Siti Rabiatull Aisha [27] reflowed ENIG with SAC305 solder for 25 minutes up to $250^{\circ} \mathrm{C}$.

\section{Reflow Profile}

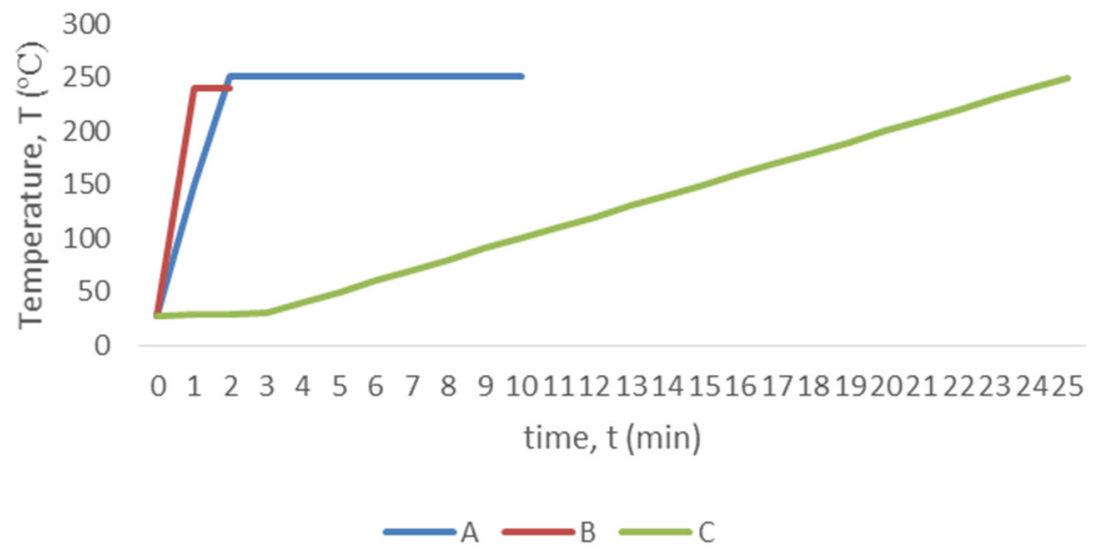

Figure 2: Reflow profile for difference studies from previous researcher.

Based on previous findings, when cooled in the oven $\left(0.35^{\circ} \mathrm{C} / \mathrm{s}\right)$, air $\left(3^{\circ} \mathrm{C} / \mathrm{s}\right)$ and water $\left(45^{\circ} \mathrm{C} / \mathrm{s}\right)$ condition, IMC grains $\left(\mathrm{Ni}_{3} \mathrm{Sn}_{4}\right)$ observed to increase as the cooling rate reduces [9]. Besides that, the amount of needle-type grains also decreases, but the amount of chunk-type and boomerang-type grains increases due to grain growth and coalescence as shown in Figure 3. This is because faster cooling rate forms finer IMC grains, and the elemental diffusion is made easy through grain boundaries [28, 29].

Investigation by Ochoa et al. [12] and $\mathrm{Ji}$ et al. [30] found that cooling rate have significant effect on secondary dendrite arm size, spacing of $\mathrm{Sn}$ rich phase and aspect ratio of $\mathrm{Ag}_{3} \mathrm{Sn}$. It was reported that for water cooled specimen, the $\mathrm{Sn}$ rich dendrite arm size and spacing were smaller compare to air cooled specimen as shown in Figure 4. $\mathrm{Ag}_{3} \mathrm{Sn}$ plate size is also significantly refined by reducing undercooling [31]. For furnace cooled, nearly eutectic microstructure was formed because of the cooling rate approached the equilibrium. Freitas et al. [32] 
mentioned that the mechanical strength is affected by the dendritic spacing as the mechanical properties of the joint may be improved when the dendrite arm spacing/cell spacing is reduced.
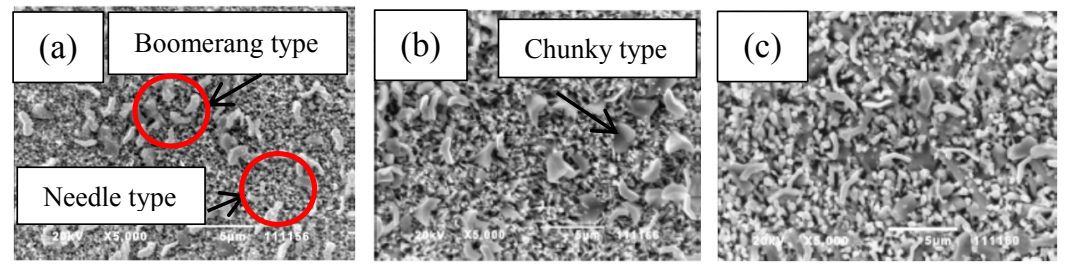

Figure 3: Top structure morphology of $\mathrm{Ni}_{3} \mathrm{Sn}_{4}$ IMC in $\mathrm{Sn}-3.5 \mathrm{Ag} / \mathrm{Ni}-\mathrm{P}$ samples reflowed for $30 \mathrm{~s}$ then cooled in different cooling rates.

(a) Fast cooling rate, (b) medium cooling rate, (c) slow cooling rate [9].
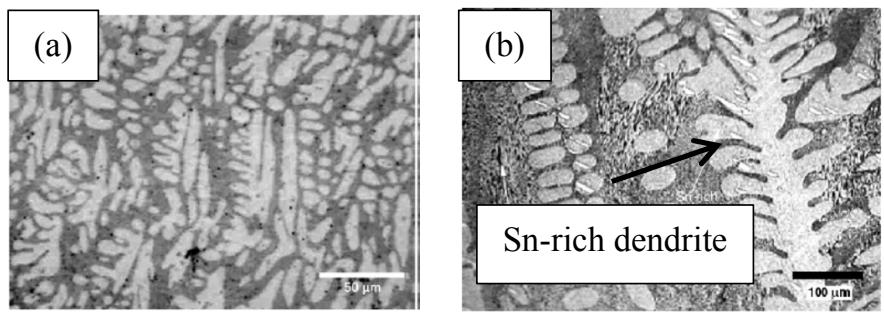

Figure 4: Optical micrographs showing the secondary size of dendrites and secondary dendrite-arm spacing: (a) water-cooled sample and (b) air cooled sample [12].

Siti Rabiatull Aisha et al. [27] reported that the faster cooling rate produced finer IMC grains which might be translated into a better solder joint strength. Reflow was conducted in air (slower cooling rate) and under nitrogen (faster cooling rate). Generally, the fast cooling rate favours nucleation but since the holding time at high temperature zone is shorter, the effective time for IMC growth is shorter. This results in the formation of a thin layer of fine grained IMCs as shown in Figures 5(a) and (b). These fine grains are in needle shape has something related with the direct reaction between $\mathrm{Sn}$ in the solder and the decomposed $\mathrm{Ni}$ from the metastable $\mathrm{Ni}$ coating (ENIG). While for the slow cooling rate, nucleation rate is lower but the IMC grains have enough time to grow. As a result, chunk type IMC becomes dominant and the IMC layer thickness is larger. So, we can say that different reflow profiles produce different morphologies of IMC at the interface during reflow which may affect the growth behaviour of the IMC after aging at the same time affect the solder strength. 


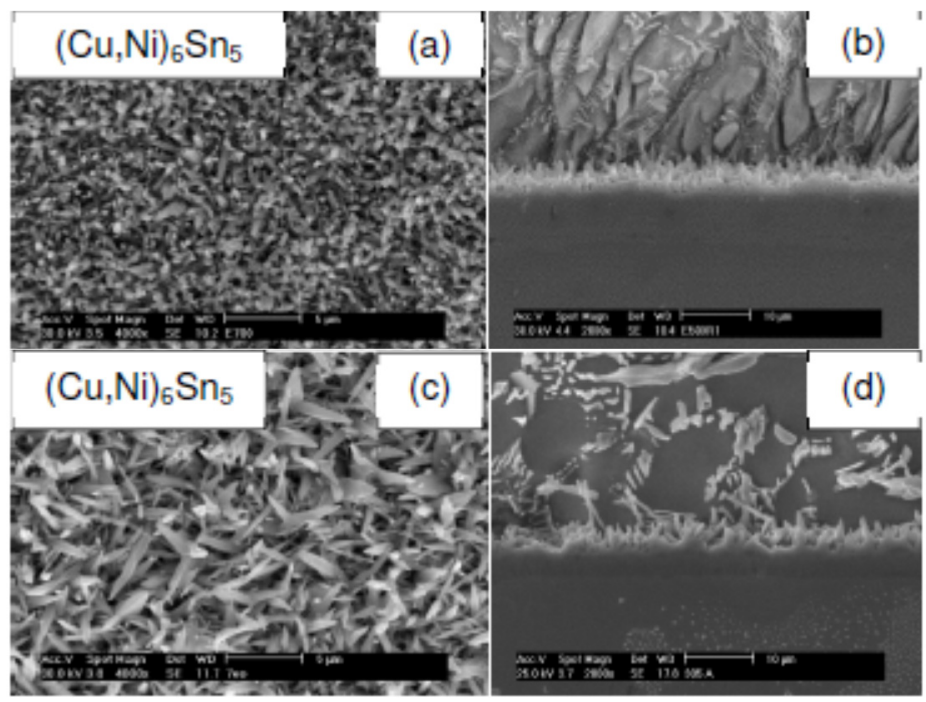

Figure 5: SEM top surface and cross sectional views of $\mathrm{Sn}-4 \mathrm{Ag}-0.5 \mathrm{Cu}$ after reflow soldering using different reflow profiles; (a), (b) fast cooling rate, and (c), (d) slow cooling rate [27].

\section{Solder joint reliability}

\subsection{Mechanical testing}

The mechanical reliability of surface finishes electroless (ENIG) and $\mathrm{Cu}$ OSP were evaluated with $\mathrm{Sn}-3.0 \mathrm{Ag}-0.5 \mathrm{Cu}$ by lap shear and four point bending tests [33]. It was found that ENIG surface provided higher max shear strength (approximately $37 \mathrm{~N}$ ) compare to Cu OSP surface finish (approximately $16 \mathrm{~N}$ ). This is due to the more brittle fracture area found on $\mathrm{Cu}$ OSP.

In a study comparing two types of surface finish, OSP and ENIG, Sundelin et al. [34] reported that when OSP exhibit higher shear strength compare to Ni/Au. However, after aging process the shear strength on $\mathrm{Ni} / \mathrm{Au}$ showed slightly decrease compare to OSP that seems to experience significant decrease where about $13 \%$ to $23 \%$. The difference in microstructure leads to this result that probably happened due to ability of $\mathrm{Ni}$ and $\mathrm{Au}$ to retard the $\mathrm{Cu}$ diffusion process. Investigation by Yoon et al. [35] supporting the findings from previous researcher [34, 36, 37] where reported that for Sn-3.5Ag-0.75Cu BGA placed on $\mathrm{Ni}(\mathrm{p}) / \mathrm{Au}$ surface finish, maximum shear force slightly decrease with increasing aging time.

For the bending test, board assemblies having ENIG-PCB joined with SAC solder showed maximum bending count which is approximately 1200 cycles compared to other samples (Figure 6). In the case of ENIG on PCB, bending reliability was more affected by solder composition than by heat treatment as there is not much difference between aging and non-aging samples [33, 38]. 


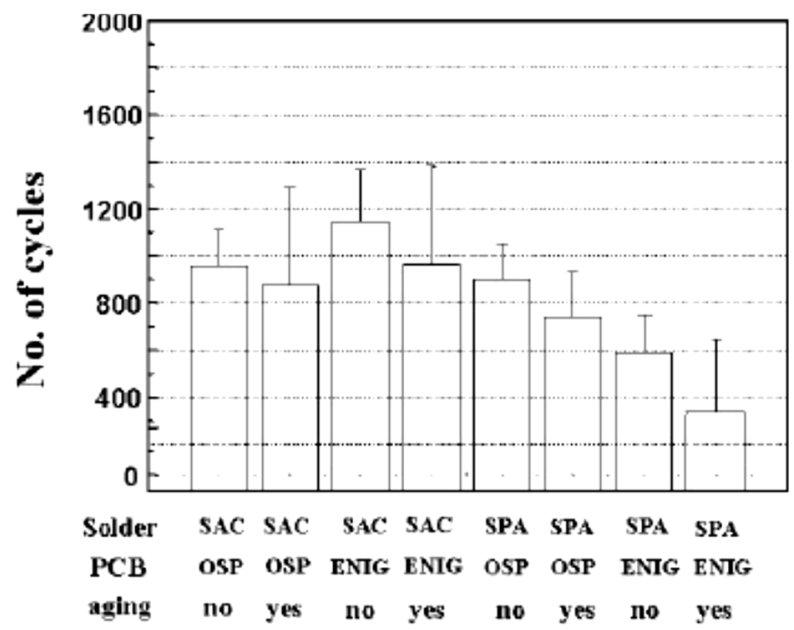

Figure 6: Mean cycles of bending to failure of the board assemblies [33].

Meanwhile, the pull strength of solder joints with OSP and ENIG finishes on PCB were compared and found that the OSP joints had higher strength [39]. It is believed that the $\mathrm{Cu}_{6} \mathrm{Sn}_{5}$ precipitates inside the bulk solder promote the reliability performance of the OSP solder [40] since the precipitates deviates the crack from the shortest distance through the joint, and slows down the propagation $[41,42]$. The phenomenon was shown in Figure 7.

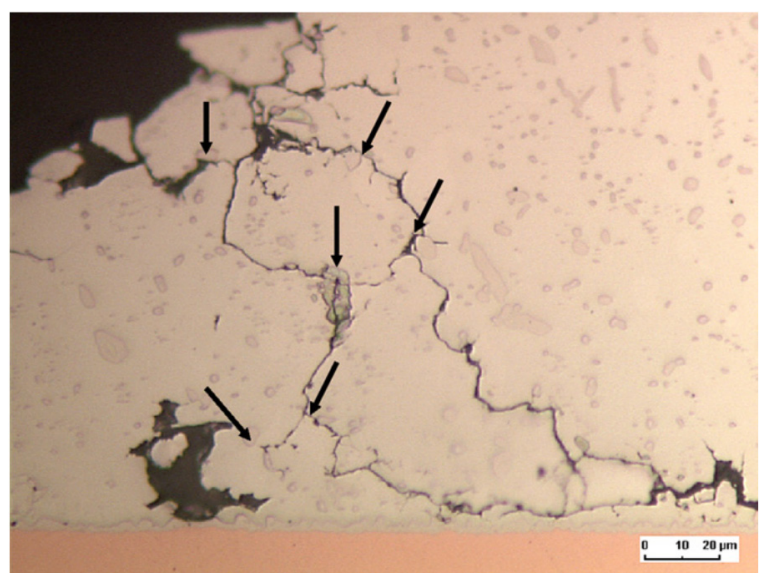

Figure 7: The propagation of crack in the bulk solder in the OSP sample [41].

\subsection{Thermal analysis}

During service condition, solder joints are subjected to thermal cycling exposure due to cyclic environment thermal excursions and/or electronic equipment power 
on-off cycles therefore, it is important to understand the effect of thermal cycling aging [37]. In terms of thermal cycle, Xia and Xie [41] in their study of the reliability of lead-free electronic assemblies under thermal cycling with OSP and ENIG surface finish found that OSP finish gave better performance than its ENIG counterparts. It was reported that for both cases, the crack originates at the fringe of heel fillet. For ENIG, the propagation of cracks was along the device/solder in interface while for OSP, the crack extends parallel to the solder/PCB interface as shown in Figure 8. It is because when using OSP finishes, many $\mathrm{Cu}_{6} \mathrm{Sn}_{5}$ precipitates from inside the bulk solder joint which resulting in better reliability performance.
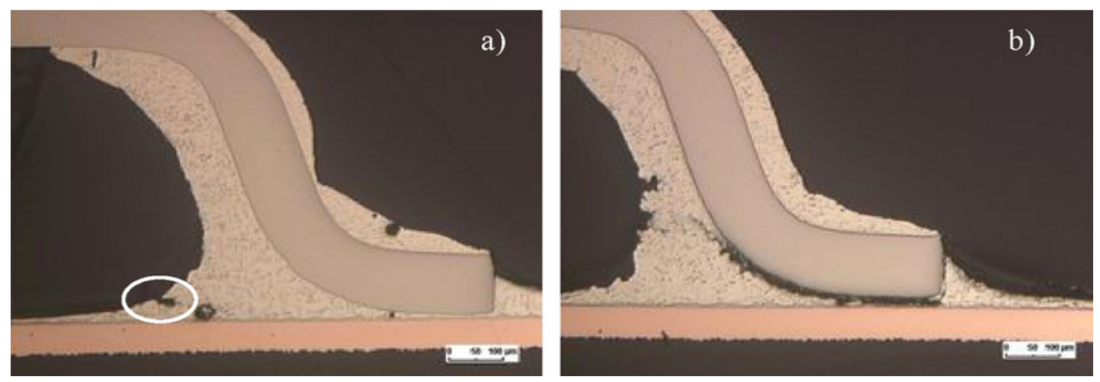

Figure 8: Typical cross-sectional optical images of samples after 6600 cycles: (a) OSP; (b) ENIG [41].

Han et al. [14] studied the relationship of thermal cycle with the solder joint strength. In the study, Sn-3.8Ag- $0.7 \mathrm{Cu}$ composite solders; nickel-carbon nano tubes ( 0 wt. $\%, 0.01$ wt. $\%, 0.03$ wt. $\%$ and 0.05 wt. $\%)$ with $\mathrm{Au} / \mathrm{Ni} / \mathrm{Cu}$ substrate samples were subjected to a cycling temperature reliability test in a three-zone furnace chamber, which follows the JEDEC standard temperature range of -40 to $+125^{\circ} \mathrm{C}$ (ramp rate: $\sim 10^{\circ} \mathrm{C} / \mathrm{min}$; dwell time at each temperature extreme: $7 \mathrm{~min}$ ) for 300 cycles, 1000 cycles and 2000 cycles. The shear tests were conducted at room temperature and at a shear strain rate of $0.254 \mathrm{~mm} / \mathrm{min}$. The shear strength of thermally cycled solder joints all decreased with the increasing cycling duration regardless the solder type [14]. This is because the IMC layers became thicker and the ENIG layer depleted, implying the consumption of $\mathrm{Ni}$ when forming additional IMC layer during the thermal cycling process.

\section{Conclusions}

The harmful effects of lead $(\mathrm{Pb})$ on the environment and human health accelerated research and development toward a full transition to $\mathrm{Pb}$-free packaging technology. Many studies have been performed on the joint reliability and interfacial reaction between $\mathrm{Pb}$-free solders and various surface finish layers, such as $\mathrm{Cu}, \mathrm{Au} / \mathrm{Ni} / \mathrm{Cu}$ and electroless nickel-immersion gold (ENIG). The results of these previews can be concluded as below. 
(1) Interfacial reaction between solder and the substrate has a significant effect on solder joint strength that either strengthens or weakens the joint depends on the surface finish used. It was found that surface finishes that consist of extra component such as $\mathrm{Ni}$ and $\mathrm{Au}$ can provide a better barrier for $\mathrm{Cu}$ diffusion.

(2) Cooling rate found to it influences not only microstructure of solder alloy but also the morphology and growth of intermetallic compounds (IMC) formed between solder and its metallization. All these have significant affect the mechanical integrity of the joint and can be concluded as the cooling rate increase the strength also increases.

(3) To evaluate the strength of the solder joint, few tests were conducted by previous research such as shear test, bending test and thermal cyclic test. With respect to the surface finish used, the results were varied where ENIG found to have greater ability to increase strength (bending and shear test) while pull strength test and thermal cyclic showed the opposite result.

\section{References}

[1] Vivet, L., Joudrier, A.L., Tan, K.L., Morelle, J.M., Etcheberry, A., and Chalumeau, L., Influence of nickel-phosphorus surface roughness on wettability and pores formation in solder joints for high power electronic applications. Applied Surface Science, 287(0): pp. 13-21, 2013.

[2] Ho, C.-Y. and Duh, J.-G., Wetting kinetics and wettability enhancement of $\mathrm{Pd}$ added electrolytic $\mathrm{Ni}$ surface with molten $\mathrm{Sn}-3.0 \mathrm{Ag}-0.5 \mathrm{Cu}$ solder. Materials Letters, 92(0): pp. 278-280, 2013.

[3] Lee, J.H., Kim, Y.M., Hwang, J.H., and Kim, Y.-H., Wetting characteristics of $\mathrm{Cu}-\mathrm{xZn}$ layers for $\mathrm{Sn}-3.0 \mathrm{Ag}-0.5 \mathrm{Cu}$ solders. Journal of Alloys and Compounds, 567(0): pp. 10-14, 2013.

[4] Satyanarayan and Prabhu, K.N., Reactive wetting, evolution of interfacial and bulk IMCs and their effect on mechanical properties of eutectic $\mathrm{Sn}-\mathrm{Cu}$ solder alloy. Advances in Colloid and Interface Science, 166(1-2): pp. 87118, 2011.

[5] Siewiorek, A., Kudyba, A., Sobczak, N., Homa, M., Huber, Z., Adamek, Z., and Wojewoda-Budka, J., Effects of PCB Substrate Surface Finish and Flux on Solderability of Lead-Free SAC305 Alloy. Journal of Materials Engineering and Performance, 22(8): pp. 2247-2252, 2013.

[6] Kim, Y., Harr, K.-M., and Kim, Y.-H., Mechanism of the Delayed Growth of Intermetallic Compound at the Interface between $\mathrm{Sn}-4.0 \mathrm{Ag}-0.5 \mathrm{Cu}$ and $\mathrm{Cu}-\mathrm{Zn}$ Substrate. Electronic Materials Letters, 6(4): pp. 151-154, 2010.

[7] Wang, T.H., Tsai, C.-H., and Lai, Y.-S., Effect of the combination of surface finishes and solder balls on JEDEC drop reliability of chip-scale packages. Microelectronic Engineering, 98(0): pp. 1-5, 2012. 
[8] Kim, S.-H., Kim, J.-M., Yoo, S., and Park, Y.-B., Effects of surface finishes and current stressing on the interfacial reaction characteristics of $\mathrm{Sn}-1.2 \mathrm{Ag}-0.7 \mathrm{Cu}-0.4 \mathrm{In}$ solder bumps. Current Applied Physics, 13, Supplement 2(0): pp. S103-S107, 2013.

[9] He, M., Chen, Z., Qi, G., Wong, C.C., and Mhaisalkar, S.G., Effect of post-reflow cooling rate on intermetallic compound formation between Sn-3.5 Ag solder and Ni-P under bump metallization. Thin Solid Films, 462-463(0): pp. 363-369, 2004.

[10] Deghaid Pereira, P., Eduardo Spinelli, J., and Garcia, A., Combined effects of Ag content and cooling rate on microstructure and mechanical behavior of $\mathrm{Sn}-\mathrm{Ag}-\mathrm{Cu}$ solders. Materials \& Design, 45(0): pp. 377-383, 2013.

[11] Chavali, S., Singh, Y., Subbarayan, G., Bansal, A., and Ahmad, M., Effect of pad surface finish and reflow cooling rate on the microstructure and the mechanical behavior of $\mathrm{SnAgCu}$ solder alloys. Microelectronics Reliability, 53(6): pp. 892-898, 2013.

[12] Ochoa, F., Williams, J.J., and Chawla, N., Effects of cooling rate on the microstructure and tensile behavior of a Sn-3.5wt.\%Ag solder. Journal of Electronic Materials, 32(12): pp. 1414-1420, 2003.

[13] Nai, S.M.L., Wei, J., and Gupta, M., Interfacial intermetallic growth and shear strength of lead-free composite solder joints. Journal of Alloys and Compounds, 473(1-2): pp. 100-106, 2009.

[14] Han, Y.D., Jing, H.Y., Nai, S.M.L., Xu, L.Y., Tan, C.M., and Wei, J., Interfacial reaction and shear strength of Ni-coated carbon nanotubes reinforced $\mathrm{Sn}-\mathrm{Ag}-\mathrm{Cu}$ solder joints during thermal cycling. Intermetallics, 31(0): pp. 72-78, 2012.

[15] Ruihong Z, R.Z., Fu G, Zhidong X., Interfacial reaction between the electroless nickel immersion gold substrate and Sn-based solders. Microelectronics Reliability, 49: pp. 303-309, 2009.

[16] Ho, C.E., Lin, Y.C., and Wang, S.J., Sn-Ag-Cu solder reaction with $\mathrm{Au} / \mathrm{Pd} / \mathrm{Ni}(\mathrm{P})$ and $\mathrm{Au} / \mathrm{Pd}(\mathrm{P}) / \mathrm{Ni}(\mathrm{P})$ platings. Thin Solid Films, 544(0): pp. 551-556, 2013.

[17] Liu, P., Yao, P., and Liu, J., Effects of multiple reflows on interfacial reaction and shear strength of $\mathrm{SnAgCu}$ and $\mathrm{SnPb}$ solder joints with different PCB surface finishes. Journal of Alloys and Compounds, 470(12): pp. 188-194, 2009.

[18] Xia, Y., Lu, C., Chang, J., and Xie, X., Interaction of intermetallic compound formation in $\mathrm{Cu} / \mathrm{SnAgCu} / \mathrm{NiAu}$ sandwich solder joints. Journal of Electronic Materials, 35(5): pp. 897-904, 2006.

[19] Tseng, C.-F. and Duh, J.-G., Correlation between microstructure evolution and mechanical strength in the $\mathrm{Sn}-3.0 \mathrm{Ag}-0.5 \mathrm{Cu} / \mathrm{ENEPIG}$ solder joint. Materials Science and Engineering: A, 580(0): pp. 169-174, 2013.

[20] Li, C.C., Shih, W.L., Chung, C.K., and Kao, C.R., Amorphous Pd layer as a highly effective oxidation barrier for surface finish of electronic terminals. Corrosion Science, 83(0): pp. 419-422, 2014. 
[21] Lin, C.-P. and Chen, C.-M., Solid-state interfacial reactions at the solder joints employing $\mathrm{Au} / \mathrm{Pd} / \mathrm{Ni}$ and $\mathrm{Au} / \mathrm{Ni}$ as the surface finish metallizations. Microelectronics Reliability, 52(2): pp. 385-390, 2012.

[22] Baek, Y.-H., Chung, B.-M., Choi, Y.-S., Choi, J., and Huh, J.-Y., Effects of Ni3Sn4 and $(\mathrm{Cu}, \mathrm{Ni}) 6 \mathrm{Sn} 5$ intermetallic layers on cross-interaction between $\mathrm{Pd}$ and $\mathrm{Ni}$ in solder joints. Journal of Alloys and Compounds, 579(0): pp. 75-81, 2013.

[23] Kang, S.K., Shih, D.Y., Fogel, K., Lauro, P., Myung-Jin, Y., Advocate, G.G., Jr., Griffin, M., Goldsmith, C., Henderson, D.W., Gosselin, T.A., King, D.E., Konrad, J.J., Sarkhel, A., and Puttlitz, K.J., Interfacial reaction studies on lead $(\mathrm{Pb})$-free solder alloys. Electronics Packaging Manufacturing, IEEE Transactions on, 25(3): pp. 155-161, 2002.

[24] Masui, K. and Kajihara, M., Influence of Pd on kinetics of solid-state reactive diffusion between $\mathrm{Sn}$ and $\mathrm{Ni}$. Journal of Alloys and Compounds, 485(1-2): pp. 144-149, 2009.

[25] Prabhu, K.N., Deshapande, P., and Satyanarayan, Effect of cooling rate during solidification of $\mathrm{Sn}-9 \mathrm{Zn}$ lead-free solder alloy on its microstructure, tensile strength and ductile-brittle transition temperature. Materials Science and Engineering: A, 533(0): pp. 64-70, 2012.

[26] Seo, S.-K., Kang, S., Shih, D.-Y., and Lee, H., An Investigation of Microstructure and Microhardness of $\mathrm{Sn}-\mathrm{Cu}$ and $\mathrm{Sn}-\mathrm{Ag}$ Solders as Functions of Alloy Composition and Cooling Rate. Journal of Electronic Materials, 38(2): pp. 257-265, 2009.

[27] I. Siti Rabiatull Aisha, A.O., M. A. Azmah Hanim, O. Saliza, Effect of Reflow Profile on Intermetallic Compound Formation, in OP Conf. Ser.: Mater. Sci. Eng, 2013.

[28] Li, X., Zu, F., Gao, W., Cui, X., Wang, L., and Ding, G., Effects of the melt state on the microstructure of a $\mathrm{Sn}-3.5 \% \mathrm{Ag}$ solder at different cooling rates. Applied Surface Science, 258(15): pp. 5677-5682, 2012.

[29] Guoqiang, W. and Lei, W. Effects of cooling rate on microstructure and microhardness of lead-free $\mathrm{Sn}-3.0 \mathrm{Ag}-0.5 \mathrm{Cu}$ solder. in Electronic Packaging Technology and High Density Packaging (ICEPT-HDP), 2012 13th International Conference, 2012.

[30] Ji, H., Wang, Q., Li, M., and Wang, C., Effects of ultrasonic irradiation and cooling rate on the solidification microstructure of $\mathrm{Sn}-3.0 \mathrm{Ag}-0.5 \mathrm{Cu}$ alloy. Journal of Materials Processing Technology, 214(1): pp. 13-20, 2014.

[31] Kotadia, H.R., Mokhtari, O., Clode, M.P., Green, M.A., and Mannan, S.H., Intermetallic compound growth suppression at high temperature in SAC solders with $\mathrm{Zn}$ addition on $\mathrm{Cu}$ and $\mathrm{Ni}-\mathrm{P}$ substrates. Journal of Alloys and Compounds, 511(1): pp. 176-188, 2012.

[32] Freitas, E.S., Osório, W.R., Spinelli, J.E., and Garcia, A., Mechanical and corrosion resistances of a $\mathrm{Sn}-0.7 \& \# \mathrm{xa} 0 ; \mathrm{wt} . \% \mathrm{Cu}$ lead-free solder alloy. Microelectronics Reliability, 54(6-7): pp. 1392-1400, 2014.

[33] Y. K. Jee, Y.C.S., J. Yu, T.Y. Lee, H.S. Seo, K.H. Kim, J.H. Ahn, Y.M. Lee A comparative study of ENIG and $\mathrm{Cu}$ OSP surface finishes on the 
mechanical reliability of $\mathrm{Sn}-3 . \mathrm{OAg}-0.5 \mathrm{Cu}$ and $\mathrm{Sn}-36.8 \mathrm{~Pb}-0.4 \mathrm{Ag}$ Solders. 2006.

[34] Sundelin, J.J., Nurmi, S.T., Lepistö, T.K., and Ristolainen, E.O., Mechanical and microstructural properties of $\mathrm{SnAgCu}$ solder joints. Materials Science and Engineering: A, 420(1-2): pp. 55-62, 2006.

[35] Yoon, J.-W., Chun, H.-S., and Jung, S.-B., Correlation between interfacial reactions and shear strengths of $\mathrm{Sn}-\mathrm{Ag}-(\mathrm{Cu}$ and $\mathrm{Bi}-\mathrm{In}) / \mathrm{ENIG}$ plated $\mathrm{Cu}$ solder joints. Materials Science and Engineering: A, 483-484(0): pp. 731734, 2008.

[36] Tsukamoto, H., Nishimura, T., Suenaga, S., and Nogita, K., Shear and tensile impact strength of lead-free solder ball grid arrays placed on $\mathrm{Ni}$ (P)/Au surface-finished substrates. Materials Science and Engineering: B, 171(1-3): pp. 162-171, 2010.

[37] Pang, J.H.L., Low, T.H., Xiong, B.S., Luhua, X., and Neo, C.C., Thermal cycling aging effects on $\mathrm{Sn}-\mathrm{Ag}-\mathrm{Cu}$ solder joint microstructure, IMC and strength. Thin Solid Films, 462-463(0): pp. 370-375, 2004.

[38] Nakamura, T., Miyamoto, Y., Hosoi, Y., and Newman, K. Solder joint integrity of various surface finished build-up flip chip packages by 4-point monotonic bending test. in Electronic Packaging Technology Conference, 2005. EPTC 2005. Proceedings of 7th. 2005.

[39] Huang, M.K., Lee. C., Wu, Soldering SMT. pp. 3-8, 2005.

[40] Zheng, Y., Effect of surface finishes and intermetallics on the reliability of snagcu interconnects in the Department of Mechanical Engineering University of Maryland, 2005.

[41] Xia, Y. and Xie, X., Reliability of lead-free solder joints with different PCB surface finishes under thermal cycling. Journal of Alloys and Compounds, 454(1-2): pp. 174-179, 2008.

[42] Shnawah, D.A., Sabri, M.F.M., and Badruddin, I.A., A review on thermal cycling and drop impact reliability of SAC solder joint in portable electronic products. Microelectronics Reliability, 52(1): pp. 90-99, 2012. 